\title{
Changes in clinical laboratory parameters and pharmacodynamic markers in response to blinatumomab treatment of patients with relapsed/refractory ALL
}

Virginie Nägele ${ }^{1 \dagger}$, Andrea Kratzer ${ }^{1 \dagger}$, Gerhard Zugmaier ${ }^{1}$, Chris Holland ${ }^{2}$, Youssef Hijazi ${ }^{1}$, Max S. Topp ${ }^{3}$, Nicola Gökbuget ${ }^{4}$, Patrick A. Baeuerle ${ }^{1}$, Peter Kufer ${ }^{1}$, Andreas Wolf ${ }^{1}$ and Matthias Klinger $^{1 *}$ (]

\begin{abstract}
Background: Blinatumomab has shown a remission rate of $69 \%$ in an exploratory single-arm, phase II dose-escalation study in adult patients with relapsed/refractory B-precursor acute lymphoblastic leukemia (ALL). We evaluated changes in laboratory parameters and immunopharmacodynamic markers in patients who received blinatumomab in the exploratory phase II study.

Methods: Data from 36 adults with relapsed/refractory ALL receiving blinatumomab as 4-week continuous IV infusions in various dose cohorts were analyzed for changes in liver enzymes, first-dose parameters, peripheral blood cell subpopulations, and cytokine/granzyme B release. Associations with clinical response were evaluated.

Results: Liver enzymes and inflammatory parameters transiently increased primarily during the first treatment week without clinical symptoms and reversed to baseline levels thereafter. B and T cells showed expected depletion and redistribution kinetics, respectively. Similarly, thrombocytes and T cells displayed an initial decline in cell counts, whereas neutrophils peaked during the first days after infusion start. T-cell redistribution coincided with upregulation of LFA-1 and CD69. Patients who responded to blinatumomab had more pronounced T-cell expansion, which was associated with proliferation of $\mathrm{CD}^{+}$and $\mathrm{CD} 8^{+} \mathrm{T}$ cells and memory subsets. Release of cytokines and granzyme $\mathrm{B}$ primarily occurred during the first week of cycle 1, except for IL-10, which was released in subsequent cycles. Blinatumomab step-dosing was associated with lower cytokine release and lower body temperature.
\end{abstract}

Conclusions: In this study of relapsed/refractory ALL, blinatumomab-induced changes in laboratory parameters were transient and reversible. The evaluated PD markers demonstrated blinatumomab activity, and the analysis of cytokines supported the rationale for stepwise dosing.

(ClinicalTrials.gov Identifier NCT01209286.)

Keywords: Acute lymphoblastic leukemia, Blinatumomab, Bispecific, BiTE ${ }^{\circledR}$, CD19, Liver enzymes, Pharmacodynamics

\section{Background}

The CD19/CD3 bispecific T-cell engager $\left(\right.$ BiTE $\left.^{\circledR}\right)$ antibody construct blinatumomab is an adaptor protein that

\footnotetext{
*Correspondence: matthias.klinger@amgen.com

†Virginie Nägele and Andrea Kratzer contributed equally to this work

${ }^{1}$ Amgen Research (Munich) GmbH, Staffelseestrasse 2, 81477 Munich, Germany

Full list of author information is available at the end of the article
}

allows $\mathrm{T}$ cells to recognize specifically CD19-expressing $B$ cells [1], thereby directing the cytotoxic potential of the $\mathrm{T}$ cell towards the targeted B cell. Numerous preclinical studies have demonstrated this mode of action, showing complete target cell lysis at very low blinatumomab concentrations and effector-to-target cell ratios along with tumor eradication in xenograft models [2]. Clinical response to blinatumomab treatment has been evaluated 
in relapsed/refractory non-Hodgkin's lymphoma (NHL), relapsed/refractory acute lymphoblastic leukemia (ALL), and minimal residual disease (MRD)-positive ALL [3-8]. In an exploratory phase II dose-finding study in relapsed/ refractory ALL, $69 \%$ of patients achieved complete remission $(\mathrm{CR})$ or $\mathrm{CR}$ with partial hematologic recovery $(\mathrm{CRh})$ within two treatment cycles. The study identified the blinatumomab target dose as $15 \mu \mathrm{g} / \mathrm{m}^{2} /$ day using a 1-week run-in phase at $5 \mu \mathrm{g} / \mathrm{m}^{2} /$ day for mitigation of first-dose effects [6]. In long-term follow-up analysis, T-cell expansion was associated with long-term survival [9]. In the subsequent large confirmatory phase II study, $43 \%$ of patients with relapsed/refractory ALL achieved CR/CRh within the first two cycles of blinatumomab treatment [7].

The first comprehensive pharmacokinetic (PK) and pharmacodynamic (PD) analysis in response to blinatumomab treatment was conducted in patients who were in complete hematologic remission after receiving treatment for ALL but maintained MRD-positive disease, an indicator of chemotherapy resistance [10]. T-cell and B-cell distribution kinetics and markers of blinatumomab mode of action in patients with relapsed/refractory ALL, an aggressive disease with a very poor prognosis $[11,12]$, have not yet been studied. However, evaluating blinatumomab-induced PD effects in this setting is an important first step in elucidating potential biomarkers for clinical outcomes. Furthermore, PD analyses may contribute to the management of adverse events associated with the blinatumomab mode of action. For example, treatment-induced cytokine release may cause rare events of cytokine release syndrome (CRS), and blinatumomab treatment has been associated with changes in liver enzyme parameters [6, 7]. Medications or factors related to hepatic injury/dysfunction and cholestasis or biliary obstruction may cause liver enzyme elevations above normal levels even in otherwise healthy individuals [13-16]. Thus, detailed serum chemistry, including liver enzymes such as alkaline phosphatase (AP), alanine aminotransferase (ALT), aspartate aminotransferase (AST), total bilirubin, and gamma-glutamyl transferase (GGT), provides important information on a patient's liver function in response to drug treatment and may reveal druginduced hepatocellular, cholestatic or mixed liver injury [17-19].

In the present study, we analyzed for the first time changes in liver enzymes and markers of inflammation and coagulation in response to blinatumomab treatment administered to patients with relapsed/refractory ALL in the exploratory phase II dose-finding study. Furthermore, we performed a detailed assessment of the behavior of peripheral $\mathrm{T}$ and $\mathrm{B}$ cells, neutrophils, and thrombocytes and characterized the release of cytokines and the T-cell effector molecule granzyme B.

\section{Methods}

\section{Patients}

Detailed inclusion/exclusion criteria are published elsewhere [6]. Briefly, adult patients with relapsed/refractory ALL were eligible if they expressed the B-precursor phenotype and had $>5 \%$ leukemic blasts in the bone marrow. Relapse was defined as reappearance of disease after CR of 28-day duration; refractory disease was defined as not having achieved CR after induction and/or consolidation treatment. A total of 36 patients were enrolled and treated with blinatumomab. ClinicalTrials.gov identifier: NCT01209286.

\section{Study design}

Study design and dose cohorts are described in detail elsewhere [6]. Briefly, this was an open-label, multicenter, phase II study with Simon 2-stage design investigating the efficacy, adverse events, PK, and PD of blinatumomab in patients with relapsed/refractory ALL. Patients received blinatumomab continuous IV infusion at a flat dose of $15 \mu \mathrm{g} / \mathrm{m}^{2} /$ day $(n=7$; cohort 1$)$, or a stepwise dose of $5-15 \mu \mathrm{g} / \mathrm{m}^{2} /$ day $\left(5 \mu \mathrm{g} / \mathrm{m}^{2} /\right.$ day for the first 7 days and $15 \mu \mathrm{g} / \mathrm{m}^{2} /$ day thereafter; $n=5$ in cohort $2 \mathrm{a} ; n=18$ in extension cohort 3) or $5-15-30 \mu \mathrm{g} / \mathrm{m}^{2} /$ day (as in cohort 2a with an additional dose step to $30 \mu \mathrm{g} / \mathrm{m}^{2} /$ day in week 3 ; $n=6$; cohort 2 b) over 4 weeks followed by a 2-week treatment-free period (one cycle). Patients who achieved $\mathrm{CR}$ or CRh within the first two cycles could receive up to three additional treatment cycles (induction and consolidation). The core study period included screening plus the treatment period (up to five cycles).

\section{Response measurement}

The primary endpoint was achievement of $\mathrm{CR}$ or $\mathrm{CRh}$ within the first two treatment cycles. CR was defined as bone marrow blasts $\leq 5 \%$, no evidence of disease, and full recovery of peripheral blood counts (platelets $>100,000 / \mu \mathrm{L}$, hemoglobin $[\mathrm{Hb}] \geq 11 \mathrm{~g} / \mathrm{dL}$, absolute neutrophil count [ANC] $>1500 / \mu \mathrm{L}$ ); $\mathrm{CRh}$ was defined as bone marrow blasts $\leq 5 \%$, no evidence of disease, and partial recovery of peripheral blood counts (platelets $>50,000 / \mu \mathrm{L}, \mathrm{Hb} \geq 7 \mathrm{~g} / \mathrm{dL}$, ANC $>500 / \mu \mathrm{L}$ ). Bone marrow blast count was quantified by a central laboratory at screening and after each treatment cycle.

\section{Anti-blinatumomab antibodies}

Serum samples for detection of anti-blinatumomab antibodies were collected at baseline (predose), at the end of infusion of each treatment cycle, and at the end-of-corestudy visit. Anti-blinatumomab antibodies were measured with a validated electrochemiluminescence immunoassay (Meso Scale Discovery, Rockville, MD, USA). Briefly, serum samples (undiluted and prediluted 1:100 in the 
respective predose serum in order to avoid potential hook effects) were diluted 1:10 in phosphate-buffered saline and then incubated with $0.5 \mu \mathrm{g} / \mathrm{mL}$ each of biotin- and ruthenium-conjugated blinatumomab (prepared using MSD SULFO-TAG $^{\mathrm{TM}}$ [Meso Scale Discovery] following the manufacturer's instructions) for at least $1 \mathrm{~h}$ at room temperature. Samples were then added to a streptavidincoated 96-well microtiter plate (Meso Scale Discovery) blocked with $5 \%$ bovine serum albumin in phosphatebuffered saline at room temperature and incubated for $0.5-2 \mathrm{~h}$ to allow formation of antibody complexes. Antiblinatumomab antibodies in patient serum bound to biotin-conjugated/streptavidin-captured blinatumomab were recognized by ruthenium-conjugated blinatumomab. After washing with phosphate-buffered saline plus $0.05 \%$ Tween 20 and application of Reading Buffer (Meso Scale Discovery), signals were measured using a Sector Imager 2400 analyzer (Meso Scale Discovery) and normalized against a predose serum sample tested in parallel. Polyclonal goat anti-blinatumomab antibodies (Biogenes, Berlin, Germany) were included as positive control. Positive serum samples were retested in a competitive inhibition assay determining percent change in assay signal with and without blinatumomab preincubation.

\section{Pharmacokinetics}

Blood samples were collected before, during, and after infusion: baseline (day 1), days 3, 8, 15, 22, and 29 in all cohorts; and at additional time points (day $8+2 \mathrm{~h}$, day $8+6$ h; days 9,10 , and 17) in some cohorts. Biologically active concentrations of blinatumomab in serum were analyzed as described previously [20], using an assay based on CD69 upregulation on the surface of newly activated $T$ cells after dual binding of blinatumomab to HPB-ALL T cells and Raji B-lymphoma cells. The dosedependent increase of CD69 expression was measured using a fluorescence-activated cell sorter (FACS) instrument (FACSCalibur or FACSCanto II; BD Biosciences, Heidelberg, Germany). Data were analyzed using GraphPad Prism 6 software (GraphPad Software, La Jolla, CA, USA) or SoftMax Pro software (MDS Analytical Technologies, Sunnyvale, CA, USA). The assay was internally validated; the lower limit of quantification (LLOQ) was $50 \mathrm{pg} / \mathrm{mL}$. The mean steady state concentration $\left(\mathrm{C}_{\mathrm{ss}}\right)$ of blinatumomab in serum from individual patients was calculated from available data points at exposure plateau in each 4-week treatment period. For each dose cohort, the data from individual cycles were included as independent data points.

\section{Serum chemistry}

Blood samples for evaluation of clinical laboratory parameters were collected during the screening period (day -21 to day 0 ), before treatment start (baseline [day $1]$ ), and during treatment (days 2, 3, 8, 15, 22, 29) for up to 5 cycles. AST, ALT, GGT, lactate dehydrogenase (LDH), total bilirubin, and C-reactive protein (CRP) were analyzed using samples from all time points. Patient inclusion criteria were $<5 \times$ upper limit of normal (ULN) for AST, ALT or AP and $<1.5 \times$ ULN for total bilirubin [7]. Numbers of white blood cells and thrombocytes were determined from differential blood count. D-dimer concentrations were measured only in samples collected during the first two treatment cycles. No threshold values for treatment discontinuation were defined for the laboratory parameters.

\section{Lymphocyte subpopulations}

Lymphocyte subpopulations were measured either in density gradient-separated peripheral blood mononuclear cells, prepared as described previously [10], or in whole peripheral blood at screening, before treatment start (baseline), and at various time points during the infusion periods as well as at the end of the core study and at follow-up visits. Briefly, peripheral blood was collected more frequently in cohorts 1 and 2a: within $1 \mathrm{~h}$ before and at 2, 6, 24, and $48 \mathrm{~h}$ after treatment start and dose step, if any, and again once weekly until end of infusion. In cohorts $2 \mathrm{~b}$ and 3 , peripheral blood was only collected within $1 \mathrm{~h}$ before and $48 \mathrm{~h}$ after treatment start and dose step(s), and again once weekly until end of infusion. Lymphocyte subpopulations were analyzed by flow cytometric determination of different cell surface markers, obtaining measures of the relative cellular composition of the blood sample using an eight-color FACSCanto II instrument (BD Biosciences), a five-color FC500 instrument (Beckman Coulter, Brea, CA, USA), or a ten-color FACS NAVIOS instrument (Beckman Coulter). Fluorescent dye-labelled monoclonal antibodies were used to detect the following cell surface markers: CD45 (lymphocytes); CD19 (B cells); CD3, CD4, CD8 (T cells); CD69 (T-cell activation); CD45RA, CD28, CCR7 (memory T-cell subsets). T-cell adhesiveness was assessed by binding of soluble ICAM-1-Fc fusion proteins (R\&D Systems, Abingdon, UK) to (activated) LFA-1 on $\mathrm{T}$ cells, with subsequent detection by goat anti-human IgG, Fc-FITC (Dianova, Hamburg, Germany). By combining percentage values of certain lymphocyte subpopulations with the absolute lymphocyte number determined by differential blood count, the absolute numbers of the respective subpopulations were calculated.

\section{Cytokines and granzyme B}

Peripheral blood cytokine levels of interleukin (IL)-2, IL-4, IL-6, IL-10, TNF- $\alpha$, and IFN- $\gamma$ were monitored by measuring the respective markers in serum using the 
FACS-based BD Cytometric Bead Array Human Th1/ Th2 Kit II (BD Biosciences) following the manufacturer's instructions. Signals were measured using a FACSCanto II instrument and the FACS Diva evaluation software (BD Biosciences). Cytokine concentrations were calculated with the FCAP array software (Soft Flow Inc., St Louis Park, USA). The assay was internally validated; the LLOQ was $125 \mathrm{pg} / \mathrm{mL}$ and the limit of detection (LOD) was $20 \mathrm{pg} / \mathrm{mL}$. Serum samples were collected approximately $1 \mathrm{~h}$ before infusion start (baseline [day 1]); at 2, 6, 24, 48, and $168 \mathrm{~h}$ after treatment start; and at these same time points after each dose step (if applicable) in each treatment cycle for up to five cycles. For calculations of mean cytokine peak concentrations $\left(\mathrm{C}_{\max }\right)$ across all patients who received a starting dose of 5 or $15 \mu \mathrm{g} / \mathrm{m}^{2} /$ day during treatment week 1 , or $15 \mu \mathrm{g} / \mathrm{m}^{2} /$ day as second dose during treatment week 2 , and for calculations of mean and standard deviation of cytokine levels per cycle, values below LLOQ were included as such; values below LOD were set to $1 / 2$ LOD to allow logarithmic plotting. Restarted cycles following treatment interruption were considered as new cycles.

Granzyme B was monitored in parallel to cytokines in treatment cycle 1 . Serum samples were collected at the time points described above. Granzyme B was measured in triplicate using the Human Granzyme B Platinum ELISA kit (eBioscience, San Diego, USA). The assay was internally validated with an LLOQ of $100 \mathrm{pg} / \mathrm{mL}$ and an LOD of $30 \mathrm{pg} / \mathrm{mL}$. Calculations of mean granzyme $B$ peak concentrations and mean granzyme $B$ levels per cycle were performed as described above.

\section{Body temperature}

Peak body temperature was measured before treatment start (baseline); every $4 \mathrm{~h}$ within the first $12 \mathrm{~h}$ of infusion start; in the morning and evening on treatment day 2 and 3 ; and once on day 8, 15, 22 and 29. Peak body temperature was analyzed for the first treatment week in patients who received a starting dose of 5 or $15 \mu \mathrm{g} / \mathrm{m}^{2} /$ day in cycle 1 and for the second treatment week in patients who received $15 \mu \mathrm{g} / \mathrm{m}^{2} /$ day as the second dose in cycle 1 .

\section{Statistical analysis}

All data were summarized using descriptive statistics. Data are presented as mean \pm standard deviation (SD) or as median with 25 th and 75 th percentile.

\section{Results}

\section{Pharmacokinetics and anti-blinatumomab antibodies}

In this exploratory phase II study, 36 patients with relapsed/refractory ALL received blinatumomab via continuous IV infusion. In cycle 1 , treatment was administered over 4 weeks either at a flat $\left(15 \mu \mathrm{g} / \mathrm{m}^{2} /\right.$ day $)$ or stepwise dose $\left(5-15\right.$ or $5-15-30 \mu \mathrm{g} / \mathrm{m}^{2} /$ day) [6]. The mean $( \pm \mathrm{SD}) \mathrm{C}_{\mathrm{ss}}$ of blinatumomab in serum across all patients with available samples was $198( \pm 61) \mathrm{pg} / \mathrm{mL}$ at the step dose of $5 \mu \mathrm{g} / \mathrm{m}^{2} /$ day $(n=20)$ and $694( \pm 236) \mathrm{pg} / \mathrm{mL}$ at $15 \mu \mathrm{g} / \mathrm{m}^{2} /$ day $(n=32)$.

Paired pre- and post infusion blood samples were collected from 35 of the treated 36 patients (no post infusion sample was available for one patient). No anti-blinatumomab antibodies were detected in any of the samples.

\section{Transient blinatumomab-induced changes in clinical laboratory parameters}

We monitored changes in clinical laboratory parameters by analyzing serum chemistry, hematology, and coagulation over the course of blinatumomab treatment. Liver parameters showed elevated median levels of AST, ALT, and total bilirubin within $24 \mathrm{~h}$ and elevated GGT within 1 week after infusion start, followed by a decline to baseline levels by end of cycle 1 (Fig. 1a-c, e). During cycle 1 , the ULN range [19] was exceeded for AST (1.6-fold; normal range, 0-35 U/L), ALT (3.2-fold; normal range, 0-35 U/L), and GGT (1.3-fold; normal range, 9-85 U/L). After the 2-week treatment-free interval, median peak levels of total bilirubin and GGT were reached within $48 \mathrm{~h}$ and median peak levels of ALT within 1 week after infusion restart (Fig. 1b, c, e). Median levels of AST remained almost stable throughout the second treatment cycle (peak maximum on day 71) (Fig. 1a). However, the magnitude of median peak levels for ALT and total bilirubin during cycle 2 was lower than during cycle 1. In contrast, median levels of AP did not markedly change during both cycles (peak maxima on day 15/22 and day 44) (Fig. 1d) and remained, as did bilirubin, below the ULN range (41-133 U/L and 0.1-1.2 mg/ $\mathrm{dL}$, respectively) [19].

Analysis of CRP and D-dimer concentrations during cycle 1 showed similar time courses, with initial elevation of median levels after infusion start, maximum concentrations at $48 \mathrm{~h}$, and a return to baseline at the end of cycle 1 . Peak median levels were higher than the ULN range for both CRP (up to 10.8-fold; normal range, $<1.0 \mathrm{mg} / \mathrm{dL}$ ) and D-dimer (up to 19.6 -fold; normal range, $<500 \mathrm{ng} / \mathrm{mL}$ ) [19] (Fig. 1f, g). Elevations of median CRP and D-dimer levels in cycle 2 were less pronounced than in cycle 1 . Peak median LDH levels were also observed $24 \mathrm{~h}$ after infusion start (1.02-fold above the ULN range of 88-230 U/L) [19]; thereafter LDH levels did not markedly change (peak maximum at day 64) (Fig. 1h). No patients interrupted or discontinued treatment because of elevated liver or first-dose parameters (data not shown). 

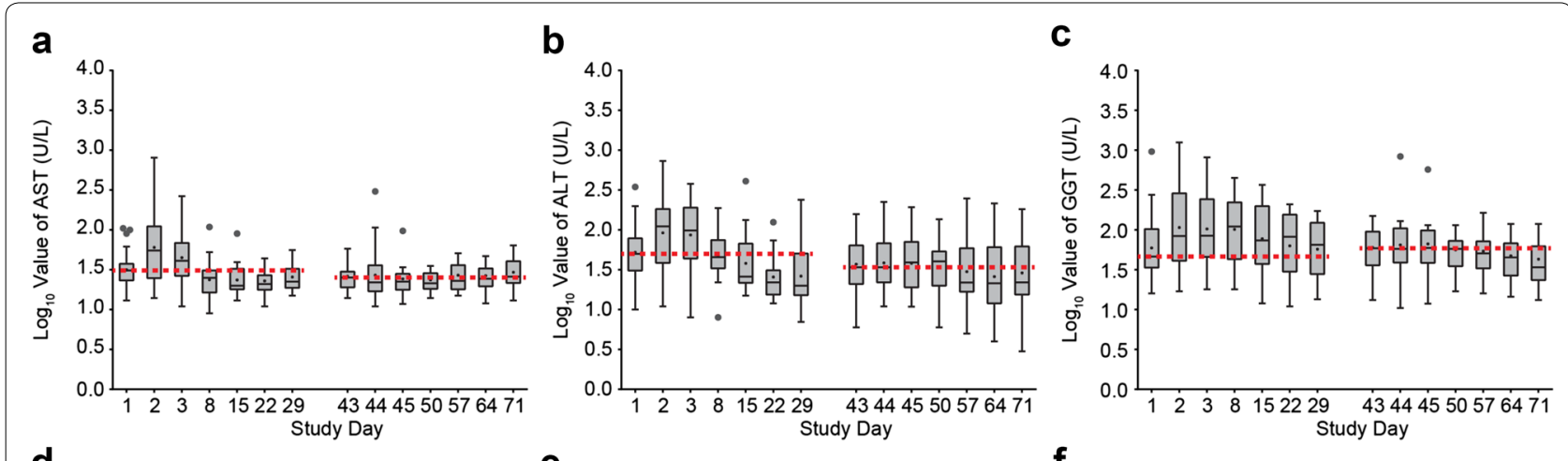

d

e

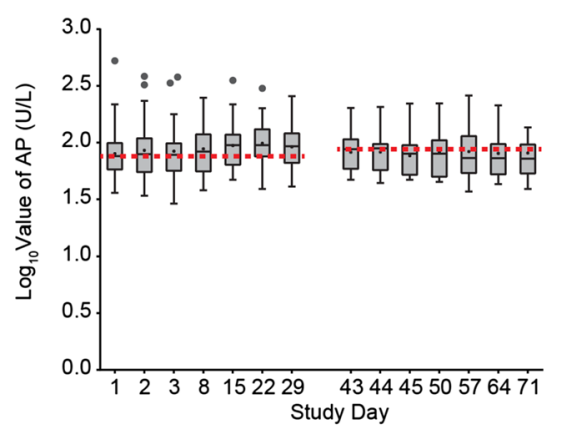

g

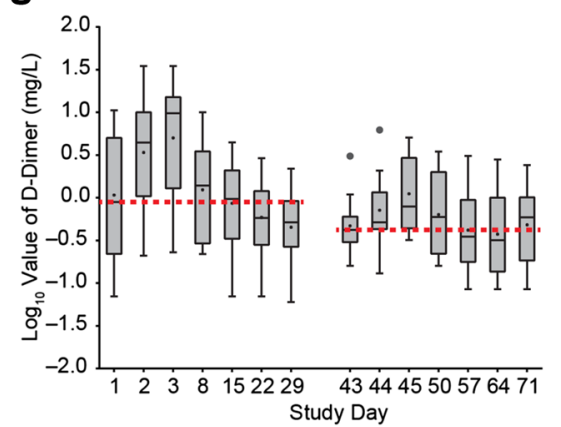

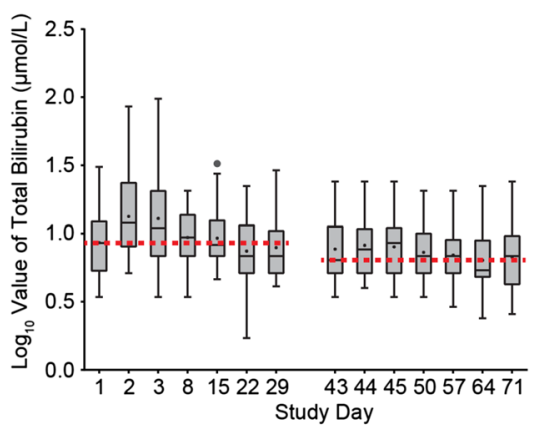

h

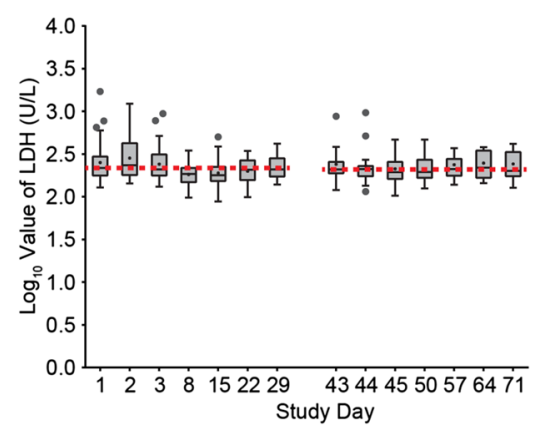

Fig. 1 Liver and first-dose parameters transiently increase primarily during the first treatment week of cycle 1. Box plots depicting logarithmic serum values of aspartate aminotransferase (AST) (a), alanine amino transferase (ALT) (b), gamma glutamyl transferase (GGT) (c), alkaline phosphatase (AP) (d), total bilirubin (e), C-reactive protein (CRP) (f), D-dimer (-g), and lactate dehydrogenase (LDH) (h) in all evaluable patients during cycle 1 and 2. Black line median levels; plus sign mean levels; circle outlying value; red dashed line baseline level in cycle 1 or cycle 2. Boxes extend from the 25th to 75th percentile, with bars extending to the minimum and maximum values within 1.5 times the interquartile range (difference between the 25th and 75th percentile). Corresponding patient numbers are shown in Additional file 1

\section{Blinatumomab-induced changes in peripheral blood cell subpopulations}

Time courses of neutrophils, thrombocytes, T cells, and $\mathrm{B}$ cells during blinatumomab treatment were stratified by responders and nonresponders depending on $\mathrm{CR} / \mathrm{CRh}$ response within two treatment cycles. For this analysis, 25 of the 36 patients were classified as responders and 11 as nonresponders (including two patients with partial remission and three with hypocellular bone marrow) [6].

The median neutrophil count of responders was $1.8 \times 10^{3} / \mu \mathrm{L}$ at baseline (Fig. 2a). $24 \mathrm{~h}$ after infusion start, the median neutrophil count decreased, reaching a nadir of $0.6 \times 10^{3} / \mu \mathrm{L}$ cells after one treatment week before recovering nearly to baseline level at the end of cycle $1\left(2.1 \times 10^{3} / \mu \mathrm{L}\right)$. The distribution pattern was different in cycle 2 , starting with a median neutrophil count of $1.6 \times 10^{3} / \mu \mathrm{L}$ at baseline but reaching a maximum of $2.1 \times 10^{3} / \mu \mathrm{L}$ after $24 \mathrm{~h}$ before returning to $1.9 \times 10^{3} /$ $\mu \mathrm{L}$ at the end of cycle 2 . However, comparing the mean neutrophil counts of responders during cycle 1 and 2 showed a clear increase of mean neutrophil numbers after treatment start in both cycles (peak maximum of $3.5 \times 10^{3} / \mu \mathrm{L}$ at day 2 in cycle 1 and $3.2 \times 10^{3} / \mu \mathrm{L}$ at day 44 in cycle 2 ). 

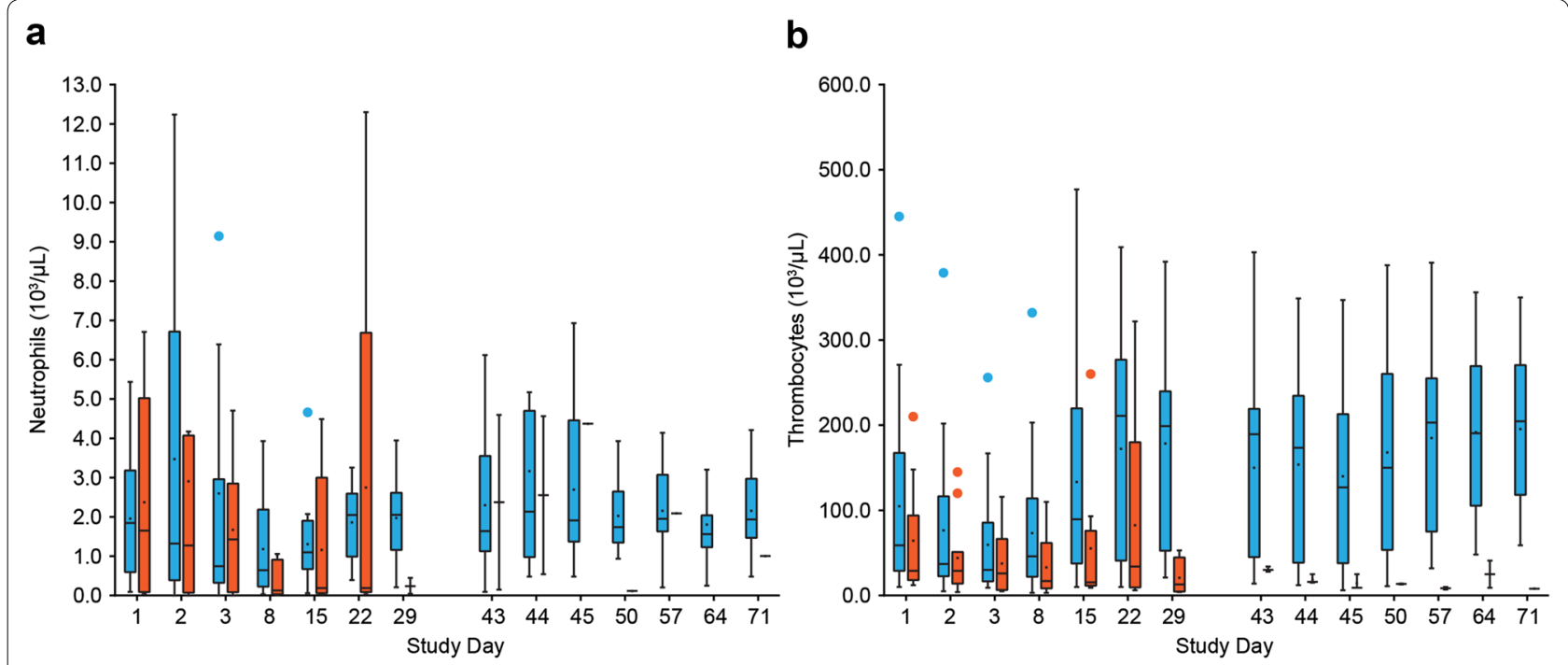

C

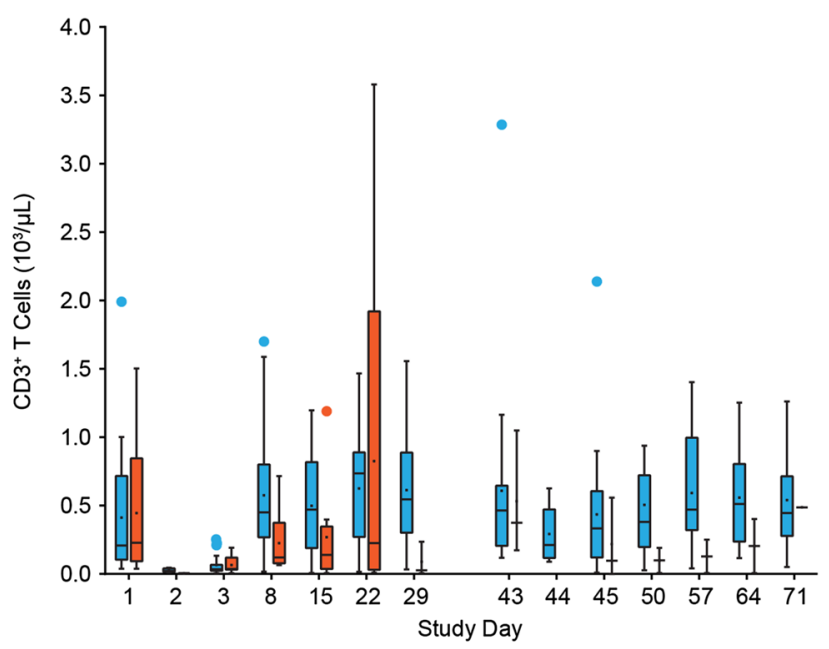

d

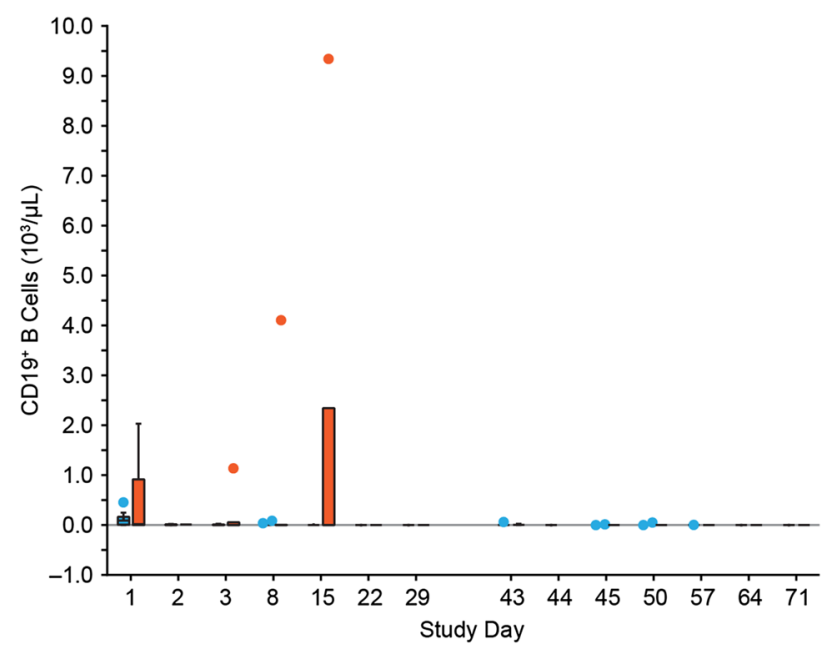

Fig. 2 Blinatumomab-induced changes in peripheral blood cell subpopulations. Redistribution of neutrophils (a) and thrombocytes (b), expansion of T cells (c), and kinetics of B-cell depletion (d) in responders versus nonresponders during treatment cycle 1 and 2. Patients were stratified into responders (blue) and nonresponders (red) based on CR/CRh response during the first two treatment cycles. Box plots depict cell counts of all evaluable patients during cycles 1 and 2. Black line median counts; plus sign mean counts; circle outlying value. Boxes extend from the 25th to 75th percentile, with bars extending to the minimum and maximum values within 1.5 times the interquartile range (difference between the 25th and 75th percentile). Corresponding patient numbers are shown in Additional file 2

Median neutrophil counts of nonresponders were $1.7 \times 10^{3} / \mu \mathrm{L}$ at baseline, reaching a nadir of $0.1 \times 10^{3} / \mu \mathrm{L}$ after 1 week. Recovery did not occur until day 29 of cycle 1 (Fig. 2a). Again, mean neutrophil counts of nonresponders in cycle 1 showed an overall increase after $24 \mathrm{~h}$ (from 2.4 to $2.9 \times 10^{3} / \mu \mathrm{L}$ ). Neutrophil kinetics of nonresponders during cycle 2 could not be analyzed because many nonresponders did not receive a second cycle, resulting in limited data availability.

Thrombocyte redistribution kinetics in responders were characterized by a low initial median thrombocyte count of $5.9 \times 10^{4} / \mu \mathrm{L}$ at baseline, reaching a nadir median cell count of $3.0 \times 10^{4} / \mu \mathrm{L} 48 \mathrm{~h}$ after infusion start before recovering to baseline level within 2 weeks (Fig. 2b). The median thrombocyte count of $19.9 \times 10^{4} / \mu \mathrm{L}$ at day 29 , comparable to that of healthy individuals, corresponded to an increase of $337 \%$ above the initial baseline value in cycle 1 . After the 2 -week treatment-free period, the median thrombocyte count of $19.0 \times 10^{4} / \mu \mathrm{L}$ in the responder group remained high for the rest of the second cycle (Fig. 2b). Nonresponders were characterized by thrombocytopenia (initial median cell count of $2.9 \times 10^{4} / \mu \mathrm{L}$ ). No marked change in thrombocyte counts until day 71 could be detected. 
$\mathrm{CD}^{+} \mathrm{T}$ cells of responders showed a similar redistribution kinetic during cycle 1 , starting with an initial median T-cell count of $2.1 \times 10^{2} / \mu \mathrm{L}$ at baseline before reaching a final median count of $5.5 \times 10^{2} / \mu \mathrm{L}$ at day 29 , which corresponds to a T-cell expansion of $262 \%$ (Fig. 2c). The median T-cell count at baseline in cycle 2 was $4.6 \times 10^{2} / \mu \mathrm{L}$, which remained almost stable until day 71 (Fig. 2c). Nonresponders had a similar initial median $\mathrm{T}$-cell count of $2.3 \times 10^{2} / \mu \mathrm{L}$ compared with responders, but no measurable expansion over the baseline level during cycle 1 .

In contrast to the above differences in peripheral blood cell kinetics between responders and nonresponders, $\mathrm{CD} 19^{+} \mathrm{B}$ cells of both patient groups rapidly declined after infusion start followed by complete B-cell depletion within the first treatment cycle, with the exception of one patient who was nonresponsive to blinatumomab therapy (Fig. 2d). Peripheral B cells of both responders and nonresponders remained undetectable throughout all subsequent treatment cycles (data not shown).

\section{Blinatumomab-induced T-cell redistribution}

T-cell redistribution kinetics were studied in more detail for patients who underwent more frequent blood sampling during the first week of blinatumomab infusion (cohorts 1 and 2a). Median $\mathrm{CD}^{+}{ }^{+} \mathrm{T}$-cell count was $1.2 \times 10^{2} / \mu \mathrm{L}$ at baseline before rapidly decreasing $2 \mathrm{~h}$ after infusion start, with a nadir of $0.2 \times 10^{2} / \mu \mathrm{L}$ reached after $6 \mathrm{~h}$. After this initial decline, median T-cell counts quickly recovered and even increased above the baseline level within the first treatment week, reaching a median T-cell count of $3.1 \times 10^{2} / \mu \mathrm{L}$ at day $8(264 \%$ above baseline) (Fig. 3a). The T-cell redistribution also coincided with upregulation of the higher affinity conformation of the adhesion molecule LFA- 1 on $\mathrm{CD}^{+} \mathrm{T}$ cells, and with upregulation of the activation marker $\mathrm{CD}^{+} 9^{+}$on both $\mathrm{CD}^{+}$and $\mathrm{CD} 4^{+} \mathrm{T}$ cells (Fig. 3b-d). The magnitude of increase from baseline was $~ 3.6$-fold for LFA-1, 3.5fold for $\mathrm{CD}^{+} / \mathrm{CD} 69^{+}$, and 3.7 -fold for $\mathrm{CD} 4^{+} / \mathrm{CD} 69^{+} \mathrm{T}$ cells, with the peak reached $24 \mathrm{~h}$ after infusion start. Values returned to baseline by the end of the first treatment week.

\section{Blinatumomab-induced T-cell expansion}

To examine the contribution of different T-cell subsets to the observed T-cell expansion, we analyzed median cell counts of $\mathrm{CD} 4^{+}$and $\mathrm{CD} 8^{+}$naïve and memory T-cell subsets during the first and second treatment cycle, and compared its kinetics between responders and nonresponders. Compared with baseline, T-cell expansion of responders was associated with increased median counts of both $\mathrm{CD}^{+} \mathrm{T}$ cells and memory $\mathrm{CD} 8^{+} \mathrm{T}$ cells $\left(\mathrm{T}_{\mathrm{CM}}+\mathrm{T}_{\mathrm{EM}}+\mathrm{T}_{\mathrm{EMRA}}\right)$ at the end of cycle 1 (243 and $195 \%$ increase above cycle 1 baseline, respectively) and cycle 2 (134 and 125\% increase above cycle 2 baseline, respectively) (Fig. 4a, c). In contrast, median counts of naive $\mathrm{CD}^{+} \mathrm{T}$ cells from responders were lower than $\mathrm{CD}^{+}$and memory $\mathrm{CD}^{+}{ }^{+}$cells, exceeding the baseline level only at the end of the first treatment cycle $(250 \%$ increase; Fig. 4b). $\mathrm{CD}^{+}$and $\mathrm{CD}^{+}{ }^{+} \mathrm{T}$-cell kinetics of responders were comparable. $\mathrm{CD} 4^{+} \mathrm{T}$ cells and memory $\mathrm{CD}^{+}{ }^{+} \mathrm{T}$ cells $\left(\mathrm{T}_{\mathrm{CM}}+\mathrm{T}_{\mathrm{EM}}\right)$ of responders expanded by 245 and $187 \%$, respectively, above baseline at the end of cycle 1 , and by 112 and $102 \%$, respectively, above baseline at the end of cycle 2 (Fig. 4d, f). Median numbers of naïve $\mathrm{CD} 4^{+} \mathrm{T}$ cells in responders were lower than $\mathrm{CD} 4^{+}$and memory $\mathrm{CD}^{+}{ }^{+} \mathrm{T}$ cells, expanding to $489 \%$ above baseline at the end of the first treatment cycle and to $216 \%$ above baseline at the end of cycle 2 (Fig. 4e). In nonresponders, median counts of $\mathrm{CD} 4^{+}$and $\mathrm{CD} 8^{+} \mathrm{T}$-cell subsets fluctuated around baseline values in cycle 1 without expansion above baseline level (Fig. 4a-f). T-cell distribution profiles of nonresponders during cycle 2 were not evaluable because of low patient numbers.

\section{Blinatumomab-induced cytokine release}

Serum samples from all 36 treated patients were analyzed for the release of IL-2, IL-4, IL-6, IL-10, TNF- $\alpha$, and IFN- $\gamma$ during the first week of treatment cycles $1-3$. Before blinatumomab infusion, all measured cytokines were below the LOD of $20 \mathrm{pg} / \mathrm{mL}$. Within the first hours after infusion start in cycle 1, levels of IL-2, IL-6, IL-10, TNF- $\alpha$, and IFN- $\gamma$, but not IL-4, increased rapidly, reaching peak mean concentrations after $2 \mathrm{~h}$ (TNF- $\alpha$ ), $6 \mathrm{~h}$ (IL-2), or $24 \mathrm{~h}$ (IL-6, IL-10, IFN- $\gamma$ ) before returning to baseline levels at the end of the 1 st week (Fig. 5a-e). Cytokines with the highest serum levels measured during cycle 1 were IL-6, IL-10, and IFN- $\gamma$. IL-10 was the only cytokine that was markedly elevated in treatment cycles 2 and 3.

\section{Mitigation of cytokine release using blinatumomab step-dosing}

Mean peak cytokine concentrations were also studied in correlation with the starting dose in cycle 1 ( 5 or $15 \mu \mathrm{g} / \mathrm{m}^{2} /$ day as first dose; $15 \mu \mathrm{g} / \mathrm{m}^{2} /$ day as second dose). Cytokine levels (IL-2, IL-6, IL-10, TNF- $\alpha$, and IFN- $\gamma$ ) were higher in patients who received a starting dose of $15 \mu \mathrm{g} / \mathrm{m}^{2} /$ day than those who received $5 \mu \mathrm{g} / \mathrm{m}^{2} /$ day (Fig. 6a). However, patients receiving $5 \mu \mathrm{g} / \mathrm{m}^{2} /$ day as the first blinatumomab dose in cycle 1 followed by $15 \mu \mathrm{g} / \mathrm{m}^{2} /$ day as second dose 1 week later showed a lower cytokine secretion at both dose levels, compared with patients who did not receive step-dosing. At the dose step to $15 \mu \mathrm{g} / \mathrm{m}^{2} /$ day, cytokine levels were even lower than at $5 \mu \mathrm{g} / \mathrm{m}^{2} /$ day (Fig. 6a). Analysis of peak body temperatures showed higher mean temperatures for those patients who started treatment at 

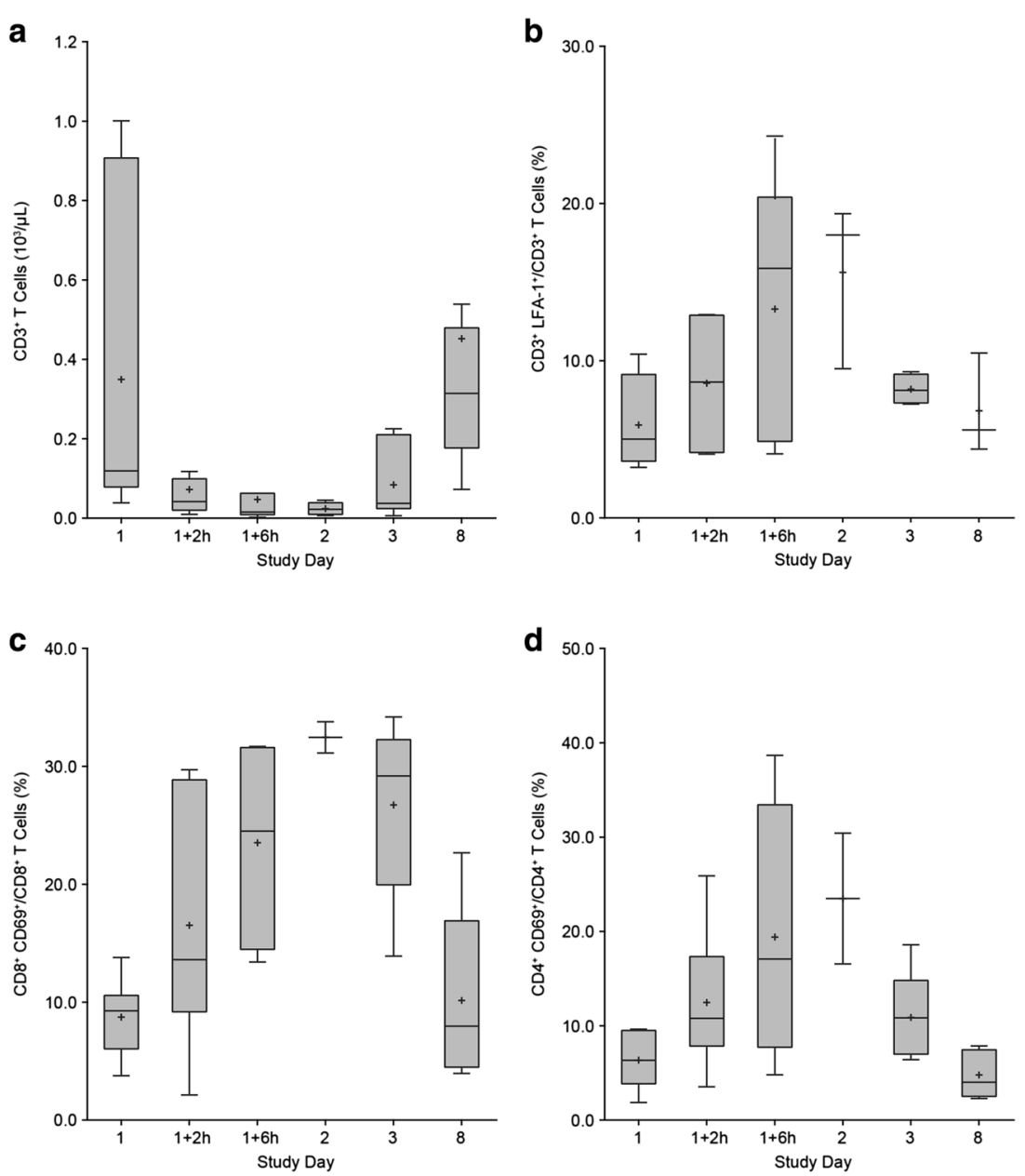

Fig. 3 T-cell redistribution during treatment week 1 coincides with activation of LFA-1 and upregulation of CD69. Boxplots depicting the CD3 ${ }^{+}$ T-cell counts of patients with frequent blood sampling during the 1 st week after start of infusion in cycle $1(\mathbf{a})$, the percentage of CD $3^{+} \mathrm{T}$ cells with activated (i.e., intermediate affinity) LFA-1 (b), the percentage of $\mathrm{CD}^{+} \mathrm{CD}^{+} 9^{+}(\mathbf{c})$, and $\mathrm{CD} 4^{+} \mathrm{CD} 69^{+} \mathrm{T}$ cells $(\mathbf{d})$. Black line median values; plus sign mean values. Boxes extend from the 25th to 75 th percentile, with bars extending to the minimum and maximum values within 1.5 times the interquartile range (difference between the 25th and 75th percentile). Corresponding patient numbers are shown in Additional file 3

a higher blinatumomab dose compared with those who received step-dosing (Fig. 6a). Higher peak body temperatures was associated with higher IL-6 peak concentrations, especially in patients who received blinatumomab flat dosing of $15 \mu \mathrm{g} / \mathrm{m}^{2} /$ day (Fig. 6b).

\section{Blinatumomab-induced cytokine and granzyme B release}

We compared mean serum concentrations of cytokines and the release of the T-cell effector molecule granzyme $B$ in responders and nonresponders during the first treatment week of cycle 1 . Patients who achieved CR/CRh appeared to have had higher mean serum concentrations of IL-6, IL-10, and IFN- $\gamma$, with peak maxima reached within the first $24 \mathrm{~h}$ after blinatumomab infusion start (Fig. 7b, c, e). In contrast, mean serum concentrations of
IL-2 and TNF- $\alpha$ were not different between both patient groups (Fig. 7a, d). Similarly, analysis of mean granzyme $B$ levels in responders and nonresponders during the first treatment week showed a comparable granzyme B kinetic for both groups, with transient elevation of granzyme B levels within the first $24 \mathrm{~h}$ after blinatumomab infusion start (Fig. 7f).

\section{Discussion}

This is the first study reporting in detail on changes in laboratory and pharmacodynamic parameters in response to blinatumomab treatment in the setting of relapsed/refractory ALL using data from an exploratory dose-finding phase II study. Changes in most of the evaluated liver and first-dose parameters were characterized 


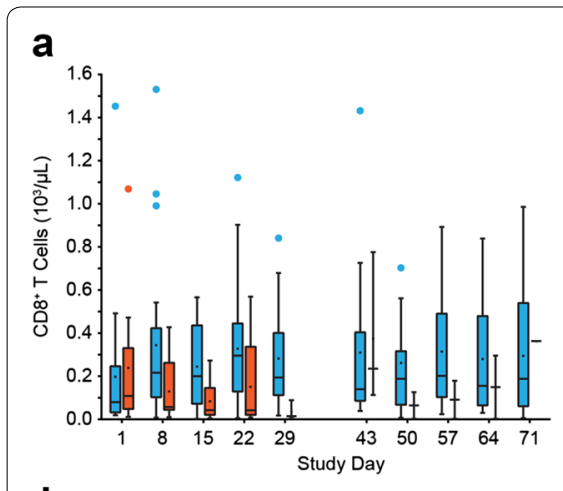

d

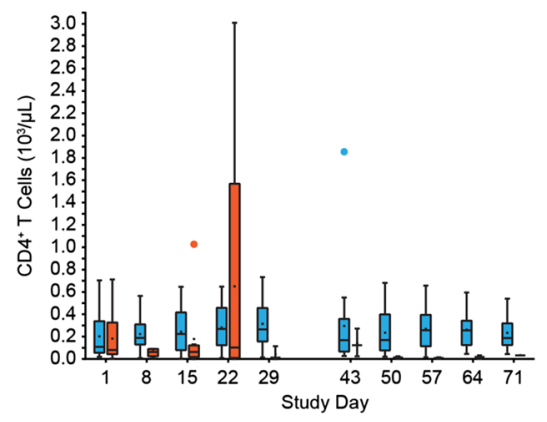

b

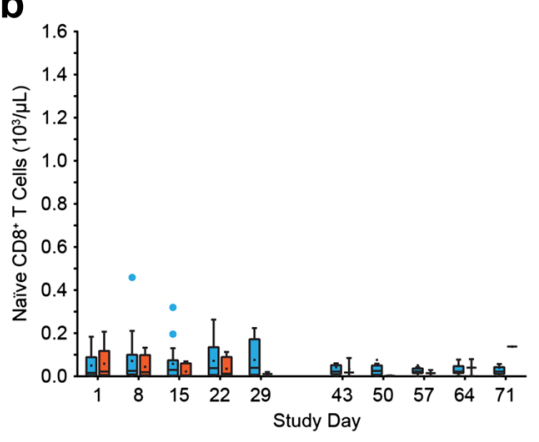

$\mathbf{e}$

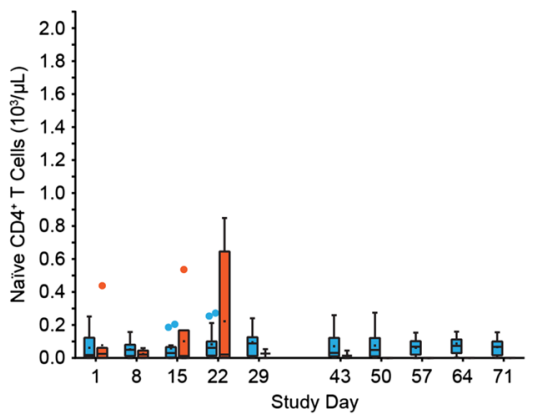

C

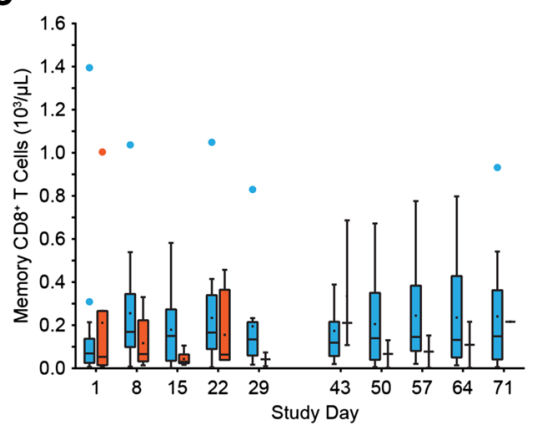

f

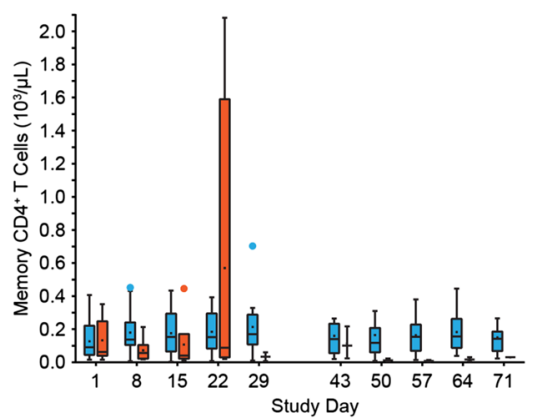

Fig. $4 \mathrm{CD}^{+}$and $\mathrm{CD}^{+}$T-cell expansion in responding patients. Patients were stratified into responders (blue) and nonresponders (red) based on CR/CRh response within the first two treatment cycles. Box plots depicting the cell counts of all evaluable patients are shown for CD8 $8^{+} \mathrm{T}$ cells $(\mathbf{a})$, naïve $C D 8^{+} T$ cells $(\mathbf{b})$, memory CD8 ${ }^{+} T$ cells $(\mathbf{c}), C D 4^{+} T$ cells $(\mathbf{d})$, naïve $C D 4^{+} \mathrm{T}$ cells $(\mathbf{e})$, and memory $C D 4^{+} \mathrm{T}$ cells $(\mathbf{f})$. Black line median counts; plus sign mean counts; circle outlying value. Boxes extend from the 25 th to 75 th percentile, with bars extending to the minimum and maximum values within 1.5 times the interquartile range (difference between the 25th and 75th percentile). Corresponding patient numbers are shown in Additional file 4

by rapid elevations immediately after infusion start and return to baseline at the end of the cycle. Specifically, ALT and AST were moderately elevated after infusion start ( $<5$ times the normal range) but decreased to baseline within the first cycle. Mild to moderately elevated ALT and AST are the most frequently observed clinical transaminase alterations $[19,21]$ and are not uncommon in response to medications as described for various other drugs, such as statins and methotrexate [22]. The observed transiently elevated levels of $\mathrm{LDH}$, which may indicate tissue damage, and D-dimer, a coagulation marker [23], might be associated with blinatumomabinduced B-cell lysis and adhesion of lymphocytes and platelets to blood vessel endothelium. Similar changes in laboratory parameters, including elevated GGT, have been described for patients with B-cell chronic lymphocytic leukemia receiving the anti-CD20 monoclonal antibody rituximab [19, 24, 25]. Importantly, the increases in liver and first-dose parameters, including CRP, a marker of infection and inflammatory processes [26], in response to blinatumomab were transient and reversible, and did not result in treatment interruptions or discontinuations. Furthermore, pronounced elevations in those parameters appear to occur early in the course of treatment when most patients with relapsed/refractory ALL receive blinatumomab in the hospital (week 1 of cycle 1 ), which would allow for careful monitoring and management, especially with respect to treatment interruptions.

Blinatumomab activates $\mathrm{T}$ cells only in the presence of $\mathrm{CD}_{1}{ }^{+}$target cells. Incubation of isolated T cells in the absence of target cells even at saturating blinatumomab concentrations has not been shown to cause expression of activation markers CD69, CD25, or release of cytokines [27-29]. Therefore, blinatumomab-induced PD effects in patients with ALL or NHL are most likely caused by activation of $\mathrm{T}$ cells after binding of accessible CD $19^{+}$target cells and formation of a cytolytic synapse. Several PD effects have been reported in studies with blinatumomab in patients with MRD-positive ALL $[6,10]$ or relapsed/refractory NHL [20]. In both settings, B-cell depletion, T-cell redistribution, and cytokine elevation were most pronounced during the first days after the start of blinatumomab infusion. The qualitative pattern of PD effects (such as transient T-cell redistribution) that occur shortly after infusion start in each treatment cycle, or after each dose step, was comparable across 


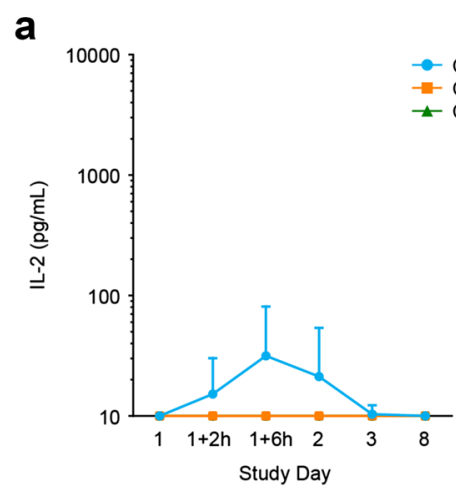

d

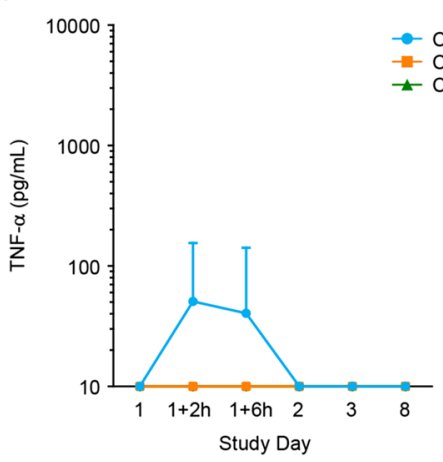

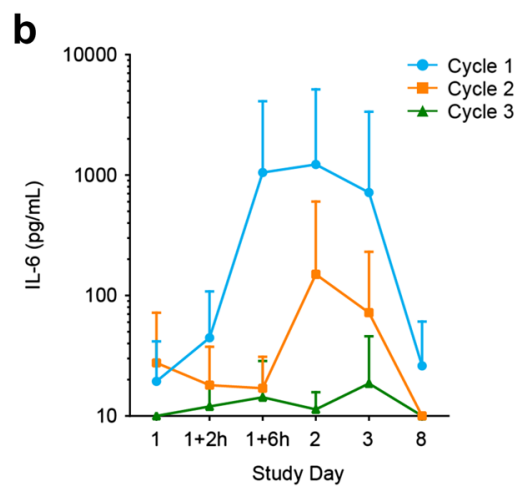
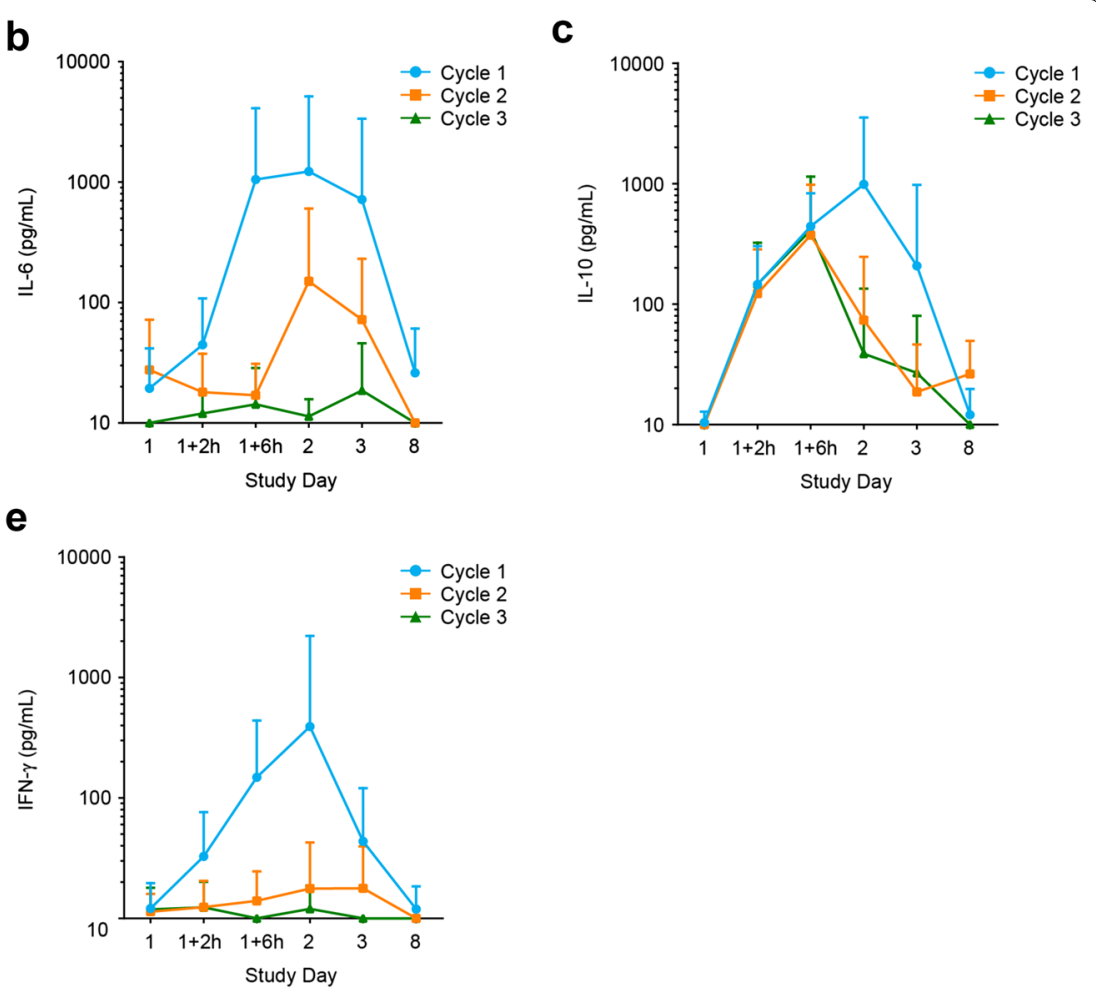

Fig. 5 Transient cytokine release primarily occurs during the first days after start of blinatumomab therapy. Mean \pm SD serum concentrations of IL-2 (a), IL-6 (b), IL-10 (c), TNF-a (d), and IFN- $\gamma(\mathbf{e})$ from all evaluable patients during the first treatment week of each of the first three cycles. Corresponding patient numbers are shown in Additional file 5

those studies. In patients with relapsed/refractory ALL, peripheral B cells rapidly declined within the first two treatment days, independent of clinical response to blinatumomab. This pattern of B-cell depletion is similar to that observed in patients with MRD-positive ALL or relapsed/refractory NHL, providing an early marker of blinatumomab activity $[10,20]$. In patients with relapsed/ refractory ALL there was an association between T-cell expansion and clinical response to blinatumomab during cycle 1, and T-cell expansion has been associated with long-term survival in this setting [9]. T-cell counts above baseline may be caused by a delayed return of $\mathrm{T}$ cells from target tissue back into peripheral blood, by $\mathrm{T}$-cell proliferation, or both. Increased $\mathrm{CD}^{+} \mathrm{T}$-cell counts of responding patients coincided with expanding $\mathrm{CD}^{+}$and $\mathrm{CD}^{+} \mathrm{T}$ cells and memory $\mathrm{T}$ cells, especially during treatment cycle 1 . Similarly, T-cell expansion has also been described for MRD-positive ALL and relapsed/ refractory NHL. In the MRD-positive ALL study, T-cell expansion above baseline was limited to the first treatment cycle and both $\mathrm{CD}^{+}{ }^{+}$and $\mathrm{CD} 8^{+} \mathrm{T}$ cells contributed to T-cell expansion, but neither was associated with response $[10,20]$. The present analysis suggests an association between T-cell expansion and clinical response to blinatumomab in relapsed/refractory ALL; however, the results are based on small numbers of patients. Appropriately designed larger studies are required to validate T-cell expansion as a biomarker for clinical response to blinatumomab treatment in this setting.

The redistribution kinetics of peripheral $\mathrm{T}$ cells in patients with relapsed/refractory ALL were also comparable to previously published data. As described for MRD-positive ALL and relapsed/refractory NHL [3, $10,20]$, peripheral $\mathrm{T}$ cells rapidly disappeared from circulation within the first day of infusion before recovering to baseline after approximately 1 week. This T-cell disappearance is most likely a consequence of increased $\mathrm{T}$-cell adhesion to blood vessel endothelium as evident from the affinity shift in the activated cell adhesion molecule LFA-1 on T cells. Simultaneously, the early activation marker CD69 was upregulated on both $\mathrm{CD}^{+}$and $\mathrm{CD}^{+} \mathrm{T}$ cells, suggesting that $\mathrm{T}$ cells were activated upon encounter with peripheral $\mathrm{B}$ cells. Involvement of both $\mathrm{CD}^{+}$and $\mathrm{CD}^{+} \mathrm{T}$ cells in redistribution and activation has been observed in all clinical studies with blinatumomab conducted to date $[4,10,20]$.

The effector molecule granzyme $B$ is stored in secretory vesicles of cytotoxic $\mathrm{T}$ cells and is released upon 

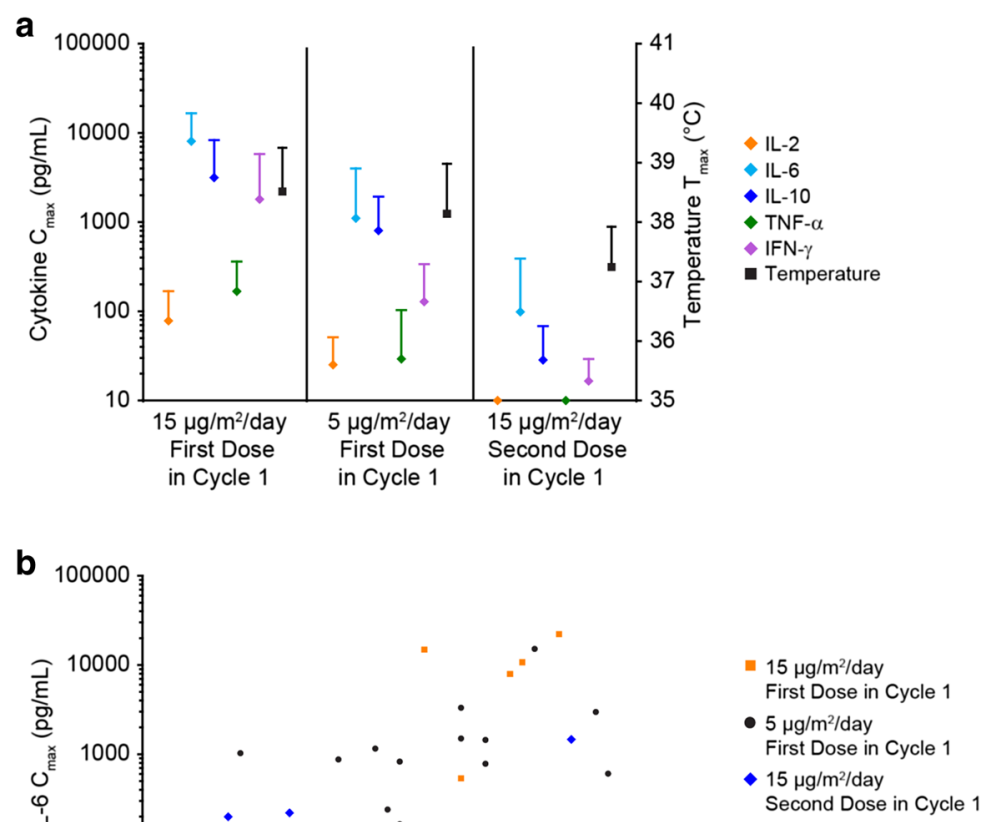

$5 \mu \mathrm{g} / \mathrm{m}^{2} / \mathrm{day}$

First Dose in Cycle 1

- $15 \mu \mathrm{g} / \mathrm{m}^{2} / \mathrm{day}$

Second Dose in Cycle 1

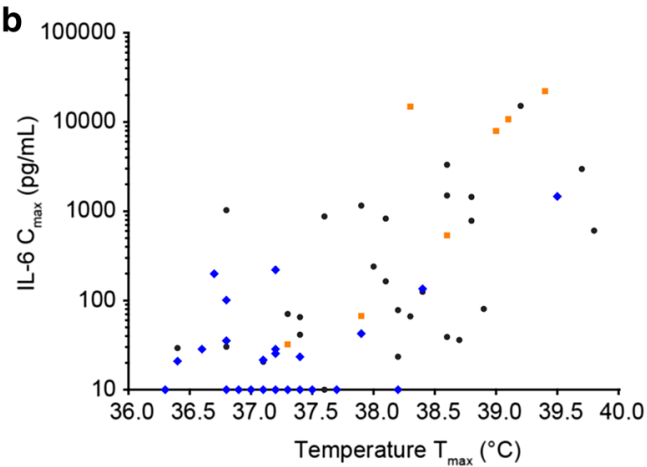

Fig. 6 Mitigation of cytokine release by blinatumomab step-dosing. a Mean peak serum concentrations $\left(C_{\max }\right) \pm S D$ of cytokines IL-2, IL-6, IL-10, TNF-a, IFN- $\gamma$ and mean peak body temperature $\left(T_{\text {max }}\right) \pm S D$ in patients who received blinatumomab doses of either 5 or $15 \mu \mathrm{g} / \mathrm{m}^{2} / \mathrm{day}$ as first dose during treatment week 1 , or $15 \mu \mathrm{g} / \mathrm{m}^{2} /$ day as second dose in week 2. $\mathbf{b} C_{\max }$ of IL-6 and $T_{\max }$ in patients receiving different blinatumomab doses during week 1 or 2 . Orange $15 \mu \mathrm{g} / \mathrm{m}^{2} /$ day flat dose; black $5 \mu \mathrm{g} / \mathrm{m}^{2} /$ day first dose in cycle 1; blue $15 \mu \mathrm{g} / \mathrm{m}^{2} /$ day second dose in cycle 1 . Corresponding patient numbers are shown in Additional file 6

formation of a blinatumomab-mediated cytolytic synapse between a $\mathrm{T}$ and $\mathrm{B}$ cell [30]. Our data show that in patients with relapsed/refractory ALL, peak levels of granzyme B during the 1st week of blinatumomab infusion were not associated with a clinical response, but its rapid appearance in serum provides additional evidence of the biologic activity of blinatumomab.

This is the first study reporting on the distribution kinetics of neutrophils and thrombocytes in patients with relapsed/refractory ALL in response to blinatumomab. Both responders and nonresponders had low platelet counts before infusion start. Thrombocytopenia is frequently associated with polychemotherapy, a common treatment for relapsed/refractory ALL, and bone marrow infiltration by blast cells, thus reflecting the disease state. After start of blinatumomab treatment, thrombocyte counts decreased further during the first treatment days before recovering and even achieving normal levels in the responder group at the end of cycle 1 . The initial platelet redistribution coincided with the described T-cell redistribution and might be explained by an increased adhesiveness of activated blood vessel endothelium, leading to platelet adhesion and disappearance from the circulation. Surprisingly, neutrophils showed the opposite behavior, with mean cell counts initially increasing after infusion start. It can be speculated that this neutrophil spike, which coincides with $\mathrm{T}$-cell redistribution, is caused by other lymphocytes and platelets displacing neutrophils from the blood vessel endothelium, thus releasing them into the circulation.

Blinatumomab treatment frequently causes fever and can cause rare events of CRS or cytokine storm, a consequence of extensive cytokine release following blinatumomab-induced T-cell activation [6, 7]. Transient elevations of cytokines during the first treatment week have been described for patients with MRD-positive ALL [10]. Those elevations were limited to cycle 1 and were not associated with clinical response. The overall pattern of released cytokines in the present study was similar; however, the anti-inflammatory cytokine IL-10 was also detectable in cycles 2 and 3 , possibly because of the larger tumor load in patients with relapsed/refractory 


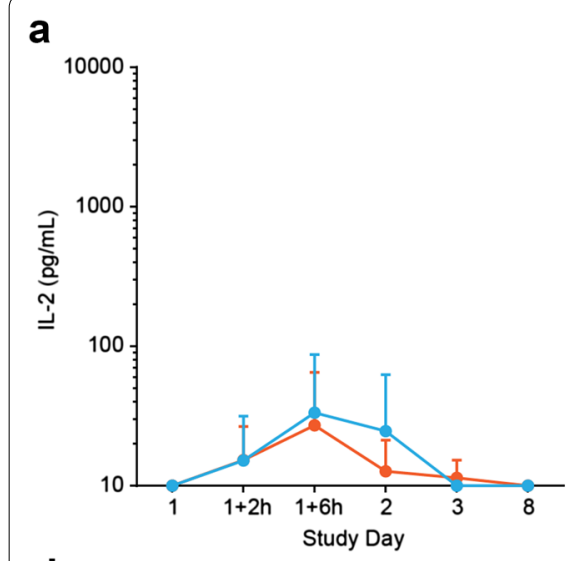

d

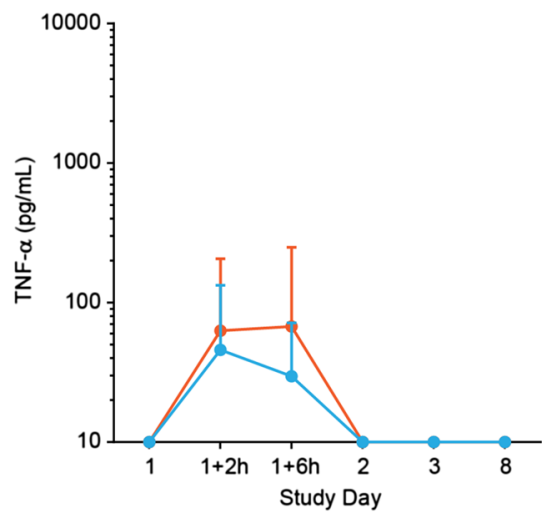

b

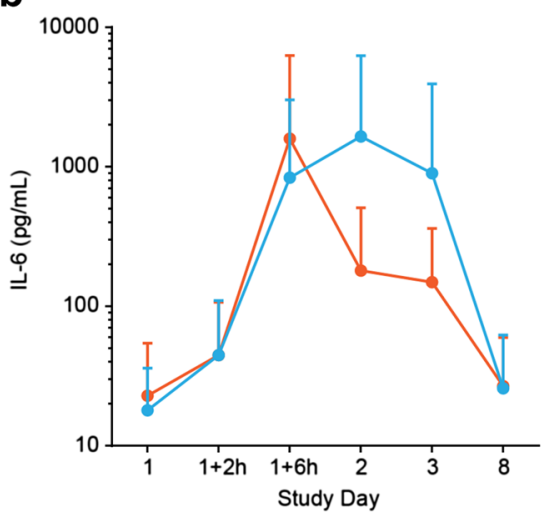

e

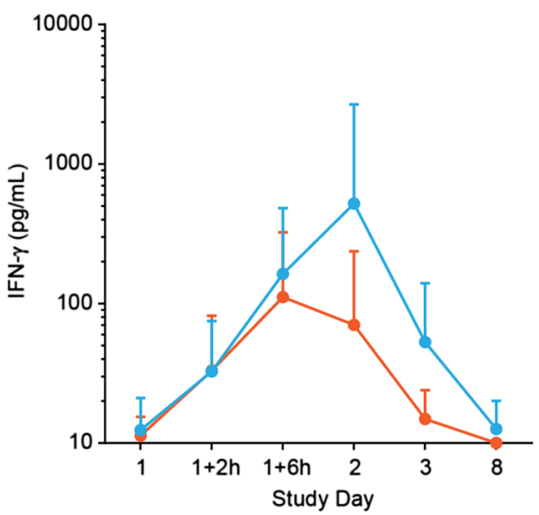

C

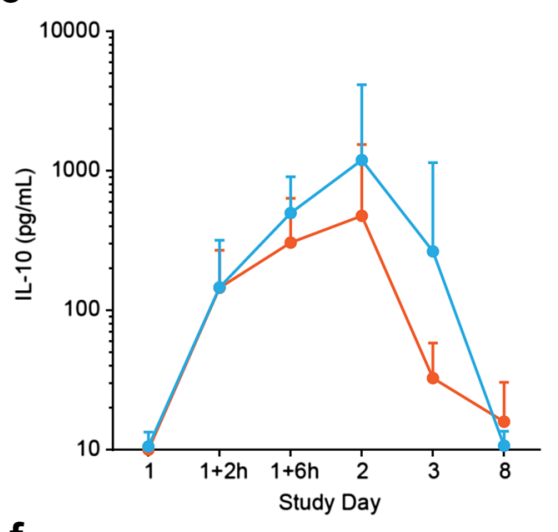

f

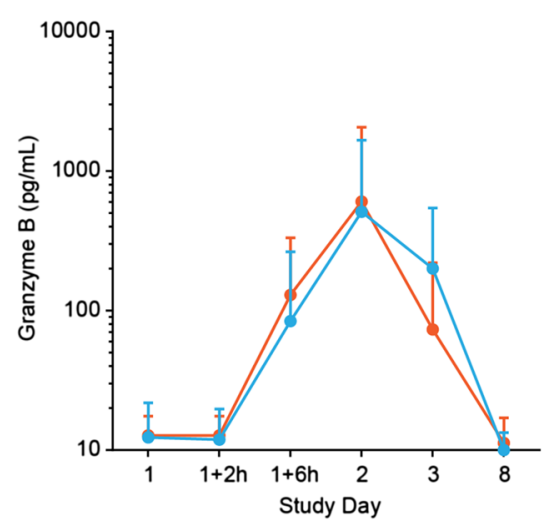

Fig. 7 Cytokine and granzyme B release during the first treatment week in responding and nonresponding patients. Patients were stratified into responders (blue) and nonresponders (red) based on $\mathrm{CR} / \mathrm{CRh}$ response within the first two treatment cycles. Mean $\pm \mathrm{SD}$ serum concentrations of IL-2 (a), IL-6 (b), IL-10 (c), TNF-a (d), IFN- $(\mathbf{e})$, and granzyme B (f) from all evaluable patients during the first treatment week are depicted on a logarithmic scale. Corresponding patient numbers are shown in Additional file 7

ALL, compared with MRD-positive ALL. The magnitude of IL-6, IL-10, and IFN- $\gamma$ release was slightly higher in patients who achieved CR/CRh than in nonresponders. It may be speculated that increased IL-10 levels, or even IL- 6 or IFN- $\gamma$ levels, in the responder group were an early sign of clinical response. However, data from a larger number of evaluable patients are required to establish an association between cytokine release and the antileukemic activity of blinatumomab. A possible association may be supported though by the observation that IL-10 does not only possess anti-inflammatory but also immune-stimulatory properties. This has recently been described for pegylated recombinant IL-10, which stimulated the activation, expansion, and cytotoxicity of tumor-infiltrating $\mathrm{CD} 8^{+} \mathrm{T}$ cells, while increased levels of immune stimulatory cytokines and antitumor activity were observed in patients with solid tumors who received pegylated recombinant IL-10 [31].

Blinatumomab first-dose effects, including CRS, in patients with relapsed/refractory ALL have been successfully mitigated using stepwise dosing [6]. We have shown for the first time that stepwise dosing resulted in a reduction in cytokine release and in lower body temperature, which explains the better tolerability of this dosing regimen compared with flat dosing. Patients with relapsed/refractory ALL who receive stepwise dosing, especially at the beginning of therapy, experienced few cytokine-associated clinical symptoms, such as CRS or cytokine storm [6, 7]. Our data also support the administration of stepwise dosing when restarting blinatumomab treatment after CRS-associated infusion interruption once the CRS event has resolved.

\section{Conclusions}

This is the first detailed PD analysis of patients with relapsed/refractory ALL who received continuous IV infusion of the CD19-targeting BiTE ${ }^{\circledR}$ antibody construct blinatumomab. The findings identify for future evaluation possible biomarkers for clinical response in a disease setting characterized by high tumor load and 
poor prognosis, and provide a clear rationale for blinatumomab step-dosing.

\section{Additional files}

Additional file 1. Available patient numbers $(\mathrm{N})$ for analysis of liver and first-dose parameters in Fig. 1.

Additional file 2. Available patient numbers ( $N$ ) for analysis of distribution profiles of neutrophils, thrombocytes, T cells and B cells in Fig. 2.

Additional file 3. Available patient numbers ( $\mathrm{N}$ ) for analysis of T-cell redistribution, LFA activation, and CD69 upregulation in Fig. 3.

Additional file 4. Available patient numbers ( $N$ ) for analysis of distribution profiles of $\mathrm{CD}^{+}$and $\mathrm{CD}^{+}{ }^{+} \mathrm{T}$ cells and subsets in Fig. 4.

Additional file 5. Available patient numbers $(\mathrm{N})$ for analysis of cytokine profiles in Fig. 5.

Additional file 6. Available patient numbers $(\mathrm{N})$ for analysis of cytokine and body temperature peak maxima in Fig. 6.

Additional file 7. Available patient numbers $(\mathrm{N})$ for analysis of cytokine and granzyme B profiles in Fig. 7 .

\begin{abstract}
Abbreviations
ALL: acute lymphoblastic leukemia; ALT: alanine aminotransferase; ANC: absolute neutrophil count; AP: alkaline phosphatase; AST: aspartate aminotransferase; $B i T{ }^{\circledR}$ : bispecific T-cell engager; $C_{\text {max }}$ : maximum or peak concentration; CR: complete remission; $\mathrm{CRh}$ : complete remission with partial hematologic recovery; CRP: C-reactive protein; CRS: cytokine release syndrome; $C_{s s}$ : steady state concentration; FACS: fluorescence-activated cell sorter; GGT: gammaglutamyl transferase; $\mathrm{Hb}$ : hemoglobin; IFN: interferon; IL: interleukin; LDH: lactate dehydrogenase; LLOQ: lower limit of quantification; LOD: limit of detection; MRD: minimal residual disease; NHL: non-Hodgkin's lymphoma; PD: pharmacodynamics; PK: pharmacokinetics; SD: standard deviation; $\mathrm{T}_{\mathrm{CM}}$ : central memory T cells; $T_{\text {EM }}$ : effector memory T cells; $\mathrm{T}_{\mathrm{EMRA}}$ : $\mathrm{CD} 45 \mathrm{RA}{ }^{+}$effector memory T cells; TNF: tumor necrosis factor; ULN: upper limit of normal.
\end{abstract}

\section{Authors' contributions}

MK, PK, and GZ contributed to the concept and design of the experiments or of the clinical laboratory data analysis (GZ). The following authors collected data: VN and MK (FACS); AK (peripheral blood cells, granzyme B), YH (PK, cytokines), and AW (anti-blinatumomab antibodies). MST and NG collected the patient data in the clinical study. CH performed the clinical laboratory data and the responder/nonresponder analysis. VN, MK, GZ, MST, and GN interpreted the clinical laboratory data; $\mathrm{VN}, \mathrm{MK}, \mathrm{AK}, \mathrm{YH}$, and $\mathrm{AW}$ interpreted all other data; PK and PAB interpreted all data in the broader context of the literature. VN, MK, and AK wrote the manuscript. All authors read and approved the final manuscript.

\section{Author details \\ ${ }^{1}$ Amgen Research (Munich) GmbH, Staffelseestrasse 2, 81477 Munich, Ger- many. ${ }^{2}$ Amgen Inc., Rockville, MD, USA. ${ }^{3}$ Medizinische Klinik und Poliklinik II, Universitätsklinikum Würzburg, Würzburg, Germany. ${ }^{4}$ Department of Medi- cine II, Goethe University, Frankfurt, Germany.}

\section{Acknowledgements}

The authors acknowledge Beate D. Quednau, Ph.D. (Amgen Inc., Thousand Oaks, CA), and Erica S. Chevalier-Larsen, Ph.D. (Complete Healthcare Communications Inc., Chadds Ford, PA), whose work was funded by Amgen Inc., for assistance in editing and formatting of this manuscript.

Youssef Hijazi and Patrick A. Baeuerle, Amgen Research (Munich) GmbH, Munich, Germany: affiliation at the time the research was conducted.

\section{Competing interests}

VN, AK, and AW are employees of Amgen (Research) Munich GmbH and shareholders in Amgen Inc. CH is an employee of Amgen Inc. and a shareholder in Amgen Inc. and MacroGenics. GZ and MK are employees of Amgen (Research)
Munich $\mathrm{GmbH}$ and shareholders in Amgen Inc., and they received consulting fees from Amgen Inc. for work related to blinatumomab patents. PK is an employee of Amgen (Research) Munich $\mathrm{GmbH}$ and a shareholder in Amgen Inc., and he received royalties from blinatumomab-related patents. MST is a member of the Amgen Inc. speaker bureau, and he received consulting fees and other remuneration from Amgen Inc. NG received research grants, consulting fees, and other remuneration from Amgen Inc. PAB and YH have no conflicts to declare; both are former employees of Amgen (Research) Munich $\mathrm{GmbH}$.

\section{Availability of data and materials}

The datasets generated and/or analyzed for the current study are not publicly available because they represent confidential and proprietary information of Amgen Inc. but are available from the corresponding author on reasonable request.

\section{Ethics approval and consent to participate}

The study protocol was approved by the local ethics committee at each participating study site and the responsible authority of the Federal Republic of Germany. The study was conducted in accordance with the provisions of the Declaration of Helsinki and Good Clinical Practice guidelines. All patients gave written informed consent before the initiation of study-related treatment and procedures.

\section{Funding}

The study was funded by Amgen (Research) Munich $\mathrm{GmbH}$ and Amgen Inc.

\section{Publisher's Note}

Springer Nature remains neutral with regard to jurisdictional claims in published maps and institutional affiliations.

Received: 29 March 2017 Accepted: 2 May 2017

Published online: 18 May 2017

\section{References}

1. Wang K, Wei G, Liu D. CD19: a biomarker for B cell development, lymphoma diagnosis and therapy. Exp Hematol Oncol. 2012;1:36.

2. Baeuerle PA, Reinhardt C. Bispecific T-cell engaging antibodies for cancer therapy. Cancer Res. 2009;69:4941-4.

3. Topp MS, Kufer P, Gokbuget N, Goebeler M, Klinger M, Neumann S, Horst HA, RaffT, Viardot A, Schmid M, et al. Targeted therapy with the T-cellengaging antibody blinatumomab of chemotherapy-refractory minimal residual disease in B-lineage acute lymphoblastic leukemia patients results in high response rate and prolonged leukemia-free survival. J Clin Oncol. 2011;29:2493-8.

4. Topp MS, Gokbuget N, Zugmaier G, Degenhard E, Goebeler ME, Klinger M, Neumann SA, Horst HA, Raff T, Viardot A, et al. Long-term follow-up of hematologic relapse-free survival in a phase 2 study of blinatumomab in patients with MRD in B-lineage ALL. Blood. 2012;120:5185-7.

5. Goebeler ME, Knop S, Viardot A, Kufer P, Topp MS, Einsele H, Noppeney R, Hess G, Kallert S, Mackensen A, et al. Bispecific T-Cell engager (BiTE) antibody construct blinatumomab for the treatment of patients with relapsed/refractory non-hodgkin lymphoma: final results from a phase Study. J Clin Oncol. 2016;34:1104-11.

6. Topp MS, Gokbuget N, Zugmaier G, Klappers P, Stelljes M, Neumann S, Viardot A, Marks R, Diedrich H, Faul C, et al. Phase II trial of the anti-CD19 bispecific $T$ cell-engager blinatumomab shows hematologic and molecular remissions in patients with relapsed or refractory B-precursor acute lymphoblastic leukemia. J Clin Oncol. 2014;32:4134-40.

7. Topp MS, Gokbuget N, Stein AS, Zugmaier G, O'Brien S, Bargou RC, Dombret $H$, Fielding AK, Heffner L, Larson RA, et al. Safety and activity of blinatumomab for adult patients with relapsed or refractory B-precursor acute lymphoblastic leukaemia: a multicentre, single-arm, phase 2 study. Lancet Oncol. 2015;16:57-66.

8. Linder K, Gandhiraj D, Hanmantgad M, Seiter K, Liu D. Complete remission after single agent blinatumomab in a patient with pre-B acute lymphoid leukemia relapsed and refractory to three prior regimens: hyperCVAD, 
high dose cytarabine mitoxantrone and CLAG. Exp Hematol Oncol. 2015:5:20.

9. Zugmaier G, Gokbuget N, Klinger M, Viardot A, Stelljes M, Neumann S, Horst HA, Marks R, Faul C, Diedrich H, et al. Long-term survival and T-cell kinetics in relapsed/refractory ALL patients who achieved MRD response after blinatumomab treatment. Blood. 2015;126:2578-84.

10. Klinger M, Brandl C, Zugmaier G, Hijazi Y, Bargou RC, Topp MS, Gokbuget N, Neumann S, Goebeler M, Viardot A, et al. Immunopharmacologic response of patients with $B$-lineage acute lymphoblastic leukemia to continuous infusion of T cell-engaging CD19/CD3-bispecific BiTE antibody blinatumomab. Blood. 2012;119:6226-33.

11. Gokbuget N, Stanze D, Beck J, Diedrich H, Horst HA, Huttmann A, Kobbe G, Kreuzer KA, Leimer L, Reichle A, et al. Outcome of relapsed adult lymphoblastic leukemia depends on response to salvage chemotherapy, prognostic factors, and performance of stem cell transplantation. Blood. 2012;120:2032-41.

12. O'Brien S, Thomas D, Ravandi F, Faderl S, Cortes J, Borthakur G, Pierce S, Garcia-Manero G, Kantarjian HM. Outcome of adults with acute lymphocytic leukemia after second salvage therapy. Cancer. 2008;113:3186-91.

13. Green RM, Flamm S. AGA technical review on the evaluation of liver chemistry tests. Gastroenterology. 2002;123:1367-84.

14. Maor Y, Malnick S. Liver injury induced by anticancer chemotherapy and radiation therapy. Int J Hepatol. 2013;2013:815105.

15. Ghabril M, Chalasani N, Bjornsson E. Drug-induced liver injury: a clinical update. Curr Opin Gastroenterol. 2010;26:222-6.

16. Suhail M, Abdel-Hafiz H, Ali A, Fatima K, Damanhouri GA, Azhar E, Chaudhary AG, Qadri I. Potential mechanisms of hepatitis B virus induced liver injury. World J Gastroenterol. 2014;20:12462-72.

17. Chalasani NP, Hayashi PH, Bonkovsky HL, Navarro VJ, Lee WM, Fontana RJ. Practice parameters committee of the American College of G: ACG Clinical Guideline: the diagnosis and management of idiosyncratic druginduced liver injury. Am J Gastroenterol. 2014;109:950-66.

18. Senior JR. Evolution of the food and drug administration approach to liver safety assessment for new drugs: current status and challenges. Drug Saf. 2014;37(Suppl 1):S9-17.

19. Nicoll CD, Chuanyi ML. Therapeutic drug monitoring \& laboratory reference. In: Papadakis MA, McPhee SJ, editors. Current medical diagnosis \& treatment. New York: McGraw Hill/Lange. 2015. p. 1707-20 (Appendix).

20. Bargou R, Leo E, Zugmaier G, Klinger M, Goebeler M, Knop S, Noppeney R, Viardot A, Hess G, Schuler M, et al. Tumor regression in cancer patients by very low doses of a T cell-engaging antibody. Science. 2008;321:974-7.
21. Giboney PT. Mildly elevated liver transaminase levels in the asymptomatic patient. Am Fam Physician. 2005;71:1105-10.

22. Oh RC, Hustead TR. Causes and evaluation of mildly elevated liver transaminase levels. Am Fam Physician. 2011;84:1003-8.

23. Adam SS, Key NS, Greenberg CS. D-dimer antigen: current concepts and future prospects. Blood. 2009;113:2878-87.

24. Winkler U, Jensen M, Manzke O, Schulz H, Diehl V, Engert A. Cytokinerelease syndrome in patients with B-cell chronic lymphocytic leukemia and high lymphocyte counts after treatment with an anti-CD20 monoclonal antibody (rituximab, IDEC-C2B8). Blood. 1999;94:2217-24.

25. Whitfield JB. Gamma glutamyl transferase. Crit Rev Clin Lab Sci. 2001;38:263-355

26. Pepys MB, Hirschfield GM. C-reactive protein: a critical update. J Clin Invest. 2003;111:1805-12.

27. Dreier T, Baeuerle PA, Fichtner I, Grun M, Schlereth B, Lorenczewski G, Kufer P, Lutterbuse R, Riethmuller G, Gjorstrup P, Bargou RC. T cell costimulus-independent and very efficacious inhibition of tumor growth in mice bearing subcutaneous or leukemic human B cell lymphoma xenografts by a CD19-/CD3- bispecific single-chain antibody construct. J Immunol. 2003;170:4397-402.

28. Dreier T, Lorenczewski G, Brandl C, Hoffmann P, Syring U, Hanakam F, Kufer P, Riethmuller G, Bargou R, Baeuerle PA. Extremely potent, rapid and costimulation-independent cytotoxic T-cell response against lymphoma cells catalyzed by a single-chain bispecific antibody. Int J Cancer. 2002;100:690-7.

29. Hoffmann P, Hofmeister R, Brischwein K, Brandl C, Crommer S, Bargou R, Itin C, Prang N, Baeuerle PA. Serial killing of tumor cells by cytotoxic T cells redirected with a CD19-/CD3-bispecific single-chain antibody construct. Int J Cancer. 2005:115:98-104.

30. Haas C, Krinner E, Brischwein K, Hoffmann P, Lutterbuse R, Schlereth B, Kufer P, Baeuerle PA. Mode of cytotoxic action of T cell-engaging BiTE antibody MT1 10. Immunobiology. 2009;214:441-53.

31. Naing A, Papadopoulos KP, Autio KA, Ott PA, Patel MR, Wong DJ, Falchook GS, Pant S, Whiteside M, Rasco DR, et al. Safety, antitumor activity, and immune activation of pegylated recombinant human interleukin-10 (AM0010) in patients With advanced solid tumors. J Clin Oncol. 2016;34:3562-9.

\section{Submit your next manuscript to BioMed Central and we will help you at every step:}

- We accept pre-submission inquiries

- Our selector tool helps you to find the most relevant journal

- We provide round the clock customer support

- Convenient online submission

- Thorough peer review

- Inclusion in PubMed and all major indexing services

- Maximum visibility for your research

Submit your manuscript at www.biomedcentral.com/submit
C BioMed Central 